\title{
E3 Ubiquitin-Protein Ligase COP1
}

National Cancer Institute

\section{Source}

National Cancer Institute. E3 Ubiquitin-Protein Ligase COP1. NCI Thesaurus. Code

C119606.

E3 ubiquitin-protein ligase COP1 (731 aa, $80 \mathrm{kDa}$ ) is encoded by the human COP1 gene.

This protein is involved in post-translational ubiquitination of target proteins. 